\title{
SOURCE PARAMETERS OF MODERATE AND STRONG EARTHQUAKES FOR TURKEY AND ITS SURROUNDING AREA (1938-2017)
}

\author{
Kalafat D. \\ Kandilli Observatory and Earthquake Research Institute (KOERI), Boğaziçi University \\ 34684 Çengelköy-Istanbul, Turkey: kalafato@boun.edu.tr
}

\begin{abstract}
Summary. The main goal of this study is calculating earthquake source parameters with inversion technique and preparing focal mechanism - moment tensor - faulting types data bank of Turkey and surrounding area and performing regional stress analysis. Source parameters-faulting mechanisms occurred in Turkey and surrounding area, compiling them and collecting in a complete data base in order to present the researchers attention from the date which the instrumental seismology started of 1938 until these days, consist the main work package of this research. This

Keywords: focal mechanism, Turkey, moment tensor, source parameters, moment magnitude research was aimed to complete the previously made researches and updating of them. Approximately $70 \%$ of the fault parameters of all earthquakes were calculated within the scope of this study. Homogeneous and integrated data set preparation by calculating all missing parameters belonging to previous earthquakes was aimed within the scope of research. We used fault parameters such as strike, dip, rake, seismic moment, moment magnitude, $\mathrm{P}$ and $\mathrm{T}$ axes azimuths and plunges for each earthquake. We prepared regional faulting types maps at regions belonging different tectonic regimes in Turkey by using faulting parameters. In this context, a total of 1950 earthquakes $\left(\mathrm{M}_{\mathrm{w}} \geq 4.0\right)$ source parameters and fault plane solutions have been compiled and a large part of them have been calculated within the scope of the study.
\end{abstract}

(C) 2020 Earth Science Division, Azerbaijan National Academy of Sciences. All rights reserved.

\section{Introduction}

Turkey is located in the eastern Mediterranean sector of the Alpine-Himalayan orogenic belt. This area comprises the technically most active in the Mediterranean region, because the country is located at the junction of the main tectonic plates, namely, African, Arabian and Eurasian (McKenzie, 1978; Dewey and Șengör, 1979; Barka and Kandinsky-Cade, 1988; Şengör et al., 1983). Global kinematic models based on the analysis of oceanic spreading, fault system, and earthquake slip vectors indicate that Arabian plate is moving in the northnorthwest direction relative to Eurasian at an average rate of about 20-30 mm/yr (Reilinger et al., 2006). Turkey is escaping from Eastern Anatolia due to collision between Arabia and Eurasian, and trust over the African oceanic plate along the Hellenic arc. The motion is taken up by strike-slip deformation along the North Anatolian and East Anatolian faults (Fig. 1).

As a consequence of the above condition the direct impact to this country leads to continuous earthquake events. According to the statistics, over 15.000 earthquakes occur per year in Turkey (Fig. 1). An important part of these earthquakes is felt by people. This requires quick information about the earthquake, especially earthquake source parameters, specific fault type and moment magnitude.

Source parameters - faulting mechanisms occurred in Turkey and surrounding area, compiling them and collecting in a complete data base in order to present the researchers attention from the date which the instrumental seismology started of 1938 until these days, consist the main work package of this research. Many researches have been carried out internationally (Alptekin, 1973; Alptekin et al.,1985; Alsan et al.,1984; Büyükaşıkoğlu, 1979; Canıtez and Büyükaşıkoğlu,1984; Canıtez and Toksöz, 1971; Canıtez and Üçer 1967; Comninakis and Papazachos, 1972; Eyidoğan, 1983,1992; Eyidoğan et al., 1986; Eyidoğan and Jackson,1985; Jackson and McKenzie, 1984; Kalafat,1988, 1989, 1998, 2016; Kalafat et al., 2009; Kocaefe and Ataman,1976; Mercier et al., 1973; McKenzie, 1972, 1978; Nowroozi, 1972; Öcal, 1960; Öcal et al., 1968; Pınar and Kalafat, 1999; Pınar and Honkura, 


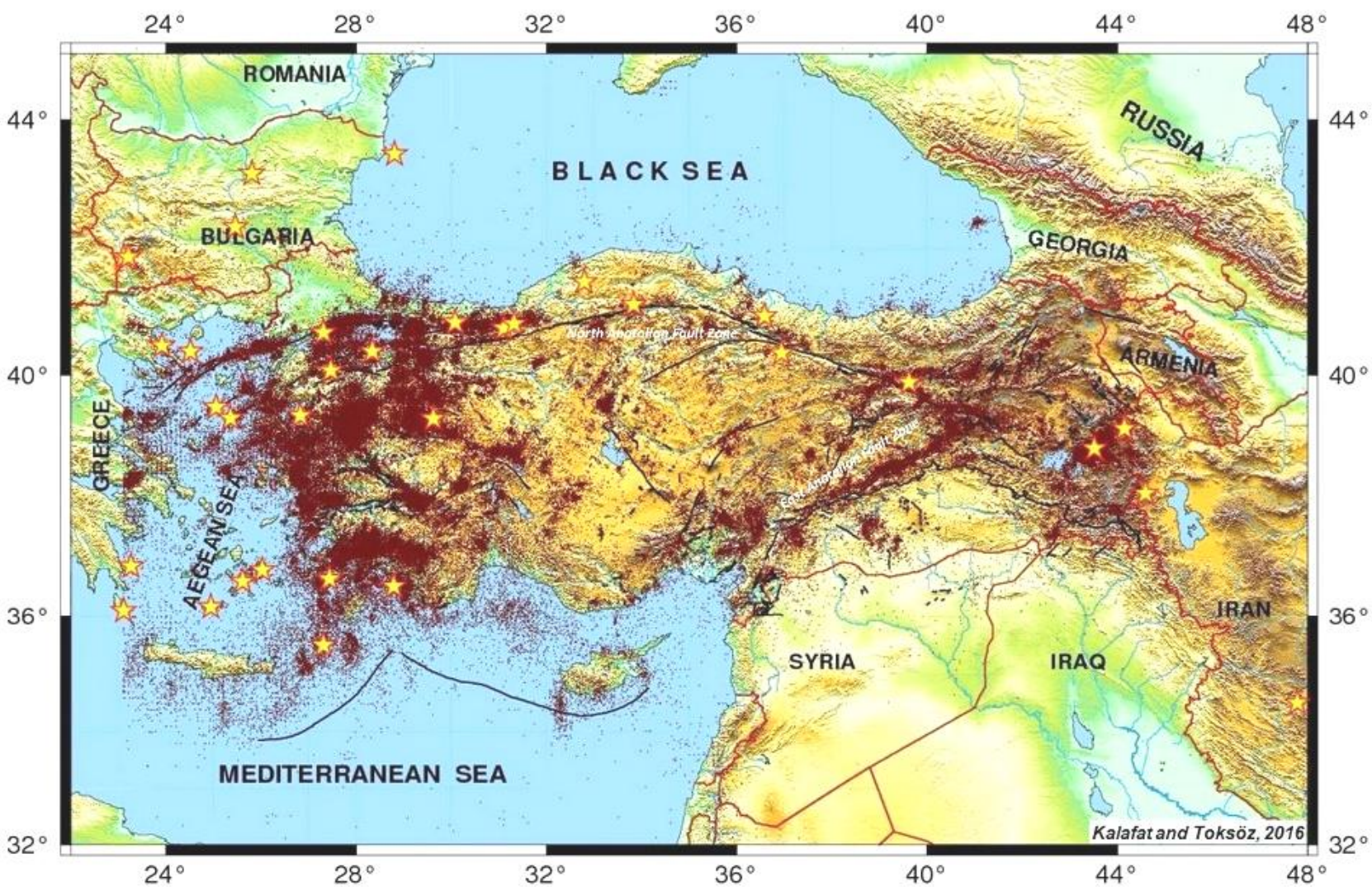

Fig. 1. Seismicity and important earthquakes (Ms>7.0) that occurred in the region during 1900-2017 (yellow stars symbols indicate magnitude $\mathrm{Ms}>7.0$ earthquakes)

1994; Pacheco et al., 1989; Stewart and Kanamori, 1982; Taymaz et al., 1991a,b; Taymaz,1993), because of the subject is one of main problems of seismology. Increasing the station and data quality accordingly, detailed studies have been performed about the subject related to the data process and developing analyze methods. A computational complete data base hasn't been generated about the subject until these days in Turkey. But only fault mechanism solutions of one or more earthquake have been carried out by scientific articles and thesis. For that reason calculating fault-source parameters of earthquakes $\left(M_{w} \geq 4.0\right)$ from 1938 until these days and gathering this information in an integrated structure to present the attention of researchers constitute the essential purposes of this research. This research was aimed to complete the previously made researches and updating of them. Homogenous and integrated data set preparation by calculating all missing parameters belonging to previous earthquakes was aimed within the scope of research.

\section{Data and Methods}

The previously performed mechanism analyses of the earthquakes occuring in the region - generally as $\mathrm{M} \geq 4.0$ have been compiled and the missing ones were solved. Kandilli Observatory and Earthquake
Research Institute (KOERI) had started to establish countrywide broadband earthquake stations especially as from 2004. In Turkey the first earthquake station with satellite connection had been established in August 2004 (Kalafat et al., 2005). Thus the analyses of earthquakes arising until 2004 had been obtained by assessing analogous records. And after 2004 the records of digital broadband stations had been used. Especially after 2004 the moment tensor analyses of earthquakes have been performed with sufficient number of digital waveform.

In this context, the instrumental period of about 1950 earthquake faulting solutions since 1938 compiled under this study and about $70 \%$ earthquakes CMT solutions have been done in the region after 2004 under this study.

Three seperate methods were used in the study.

These were as follows:

1. FOCMEC (Snoke, 2003)

2. TDMT_INV Technique (Dreger, 2002)

3. Isola (Sokos and Zaharadnik, 2013).

In this study we don't provide detailed information about using programs.

We used regionally recorded broad-band velocity waveforms for CMT solutions. We calculated usually moment tensors of the magnitude bigger 
$\mathrm{M}_{\mathrm{w}} \geq 4.0$ earthquakes. Moment Tensor Inversion Technique (TDMT_INV time-domain inversion code Dreger, 2002; Sokos and Zaharadnik, 2013) was used for the earthquakes recorded by at least 3 digital broadband seismic stations of KOERI and other neighbor seismological networks with 3-component recordings filtered by a band-pass filters described below. The quality (good signal-to-noise ratio) of the available data allowed the computation of earthquake focal mechanisms and source depths. Green's functions were calculated using the frequency-wave number integration code (FKRPROG) developed by Saikia (1994).

Once we have the location and magnitude of an event we can proceed on CMT estimation following the two stages given below:

Data preparation for inversion

CMT Inversion process.

In the first stage, the three component digital broadband waveforms are cut according to the origin time, station response is removed, the horizontal components are rotated to get the radial and transversal components, integration or derivation is applied depending on the data type to get the displacements in $\mathrm{cm}$. The modeling process is carried out using the long periods of the seismograms where the frequency range depends on the magnitude of the event. We apply the following frequency ranges for different magnitude ranges:

$\begin{array}{lll}\mathrm{M}<4 & 0.02 & -0.1 \mathrm{~Hz} \\ 4.0 \leq \mathrm{M}<5.0 & 0.02 & -0.05 \mathrm{~Hz} \\ 5.0 \leq \mathrm{M}<7.5 & 0.01 & -0.05 \mathrm{~Hz} \\ \mathrm{M} \geq 7.5 & 0.005-0.05 \mathrm{~Hz} .\end{array}$

The sampling rate of the observed and the calculated seismograms are modified to have the same sampling rate. Commonly 1-D velocity model used to locate the earthquakes in Turkey (Kalafat et al., 1987). We calculated moment tensors of the mainshocks and their strong aftershocks (Fig. 2, Fig. $3)$. A sample page from the catalog prepared within the scope of the study is given in Table.

\section{Conclusion}

The complete characterization of earthquakes focal mechanisms provide important information for scienstists and especially structural geologist working on active structures. This information is including the origin time, epicenter location, focal depth, seismic moment, the moment magnitude and spatial orientation of the 9 components of the moment tensor. And from the moment tensor we can ultimately resolve the orientation and sense of slip of the fault.

Within the scope of this study we calculated moment tensor solutions of important earthquakes in Turkey and surrounding area. We used MT catalog which scope of this work, and prepared a general type of faulting type map for Turkey and surrounding area. This map puts forth that in general so many different tectonic regimes have been still continuing in Turkey today (Fig. 4).

Current catalogue data were obtained by using general stress analysis (Gephart, 1990) by taking 7 main tectonic units that was previously determined (Fig. 5).

A brief evaluation of the stress analysis findings with respect to regions manifests that:

$1^{\text {st }}$ Region (NW Turkey - Marmara Region): Mechanism solutions exhibit that within NW Turkey and Marmara region strike slip and normal component oblique faults are widely effective. In this region P-axis directions are generally NW-SE extended.

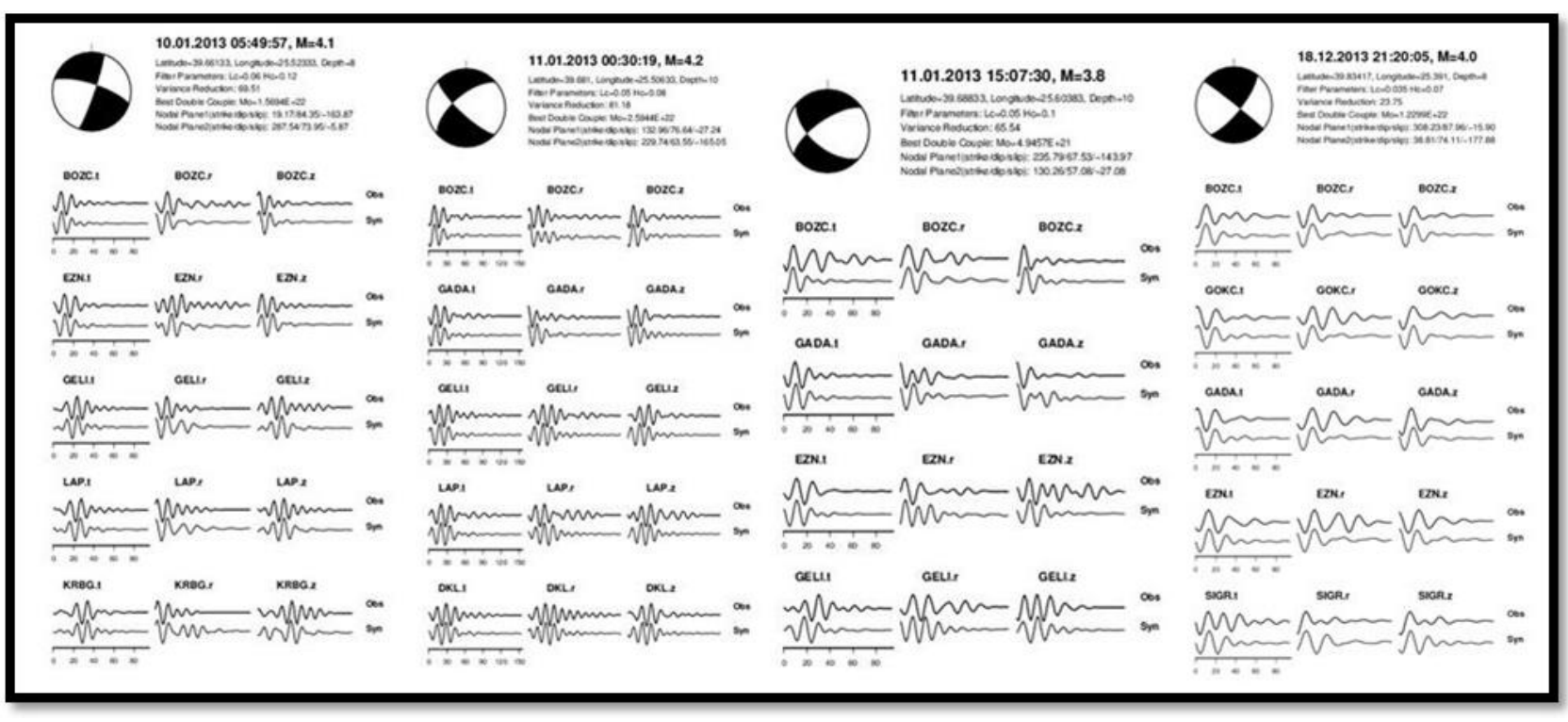

Fig. 2. Examples of inversion (used Dreger, 2002 TDMT_INV code) 


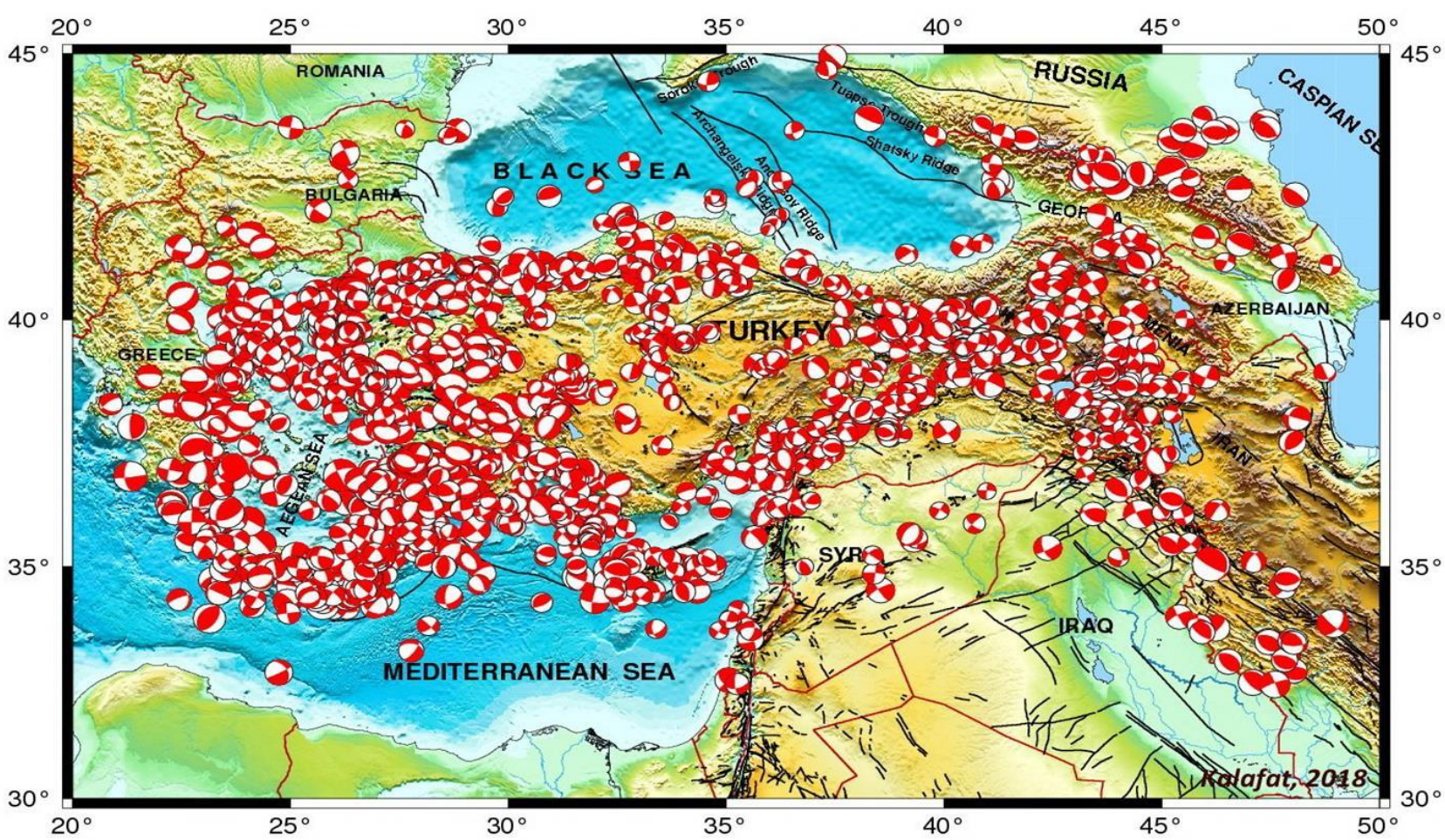

Fig. 3. Moment tensor solutions of earthquakes $\left(M_{w} \geq 4.0\right)$ that occurred during 1938-2017 in Turkey and surrounding area

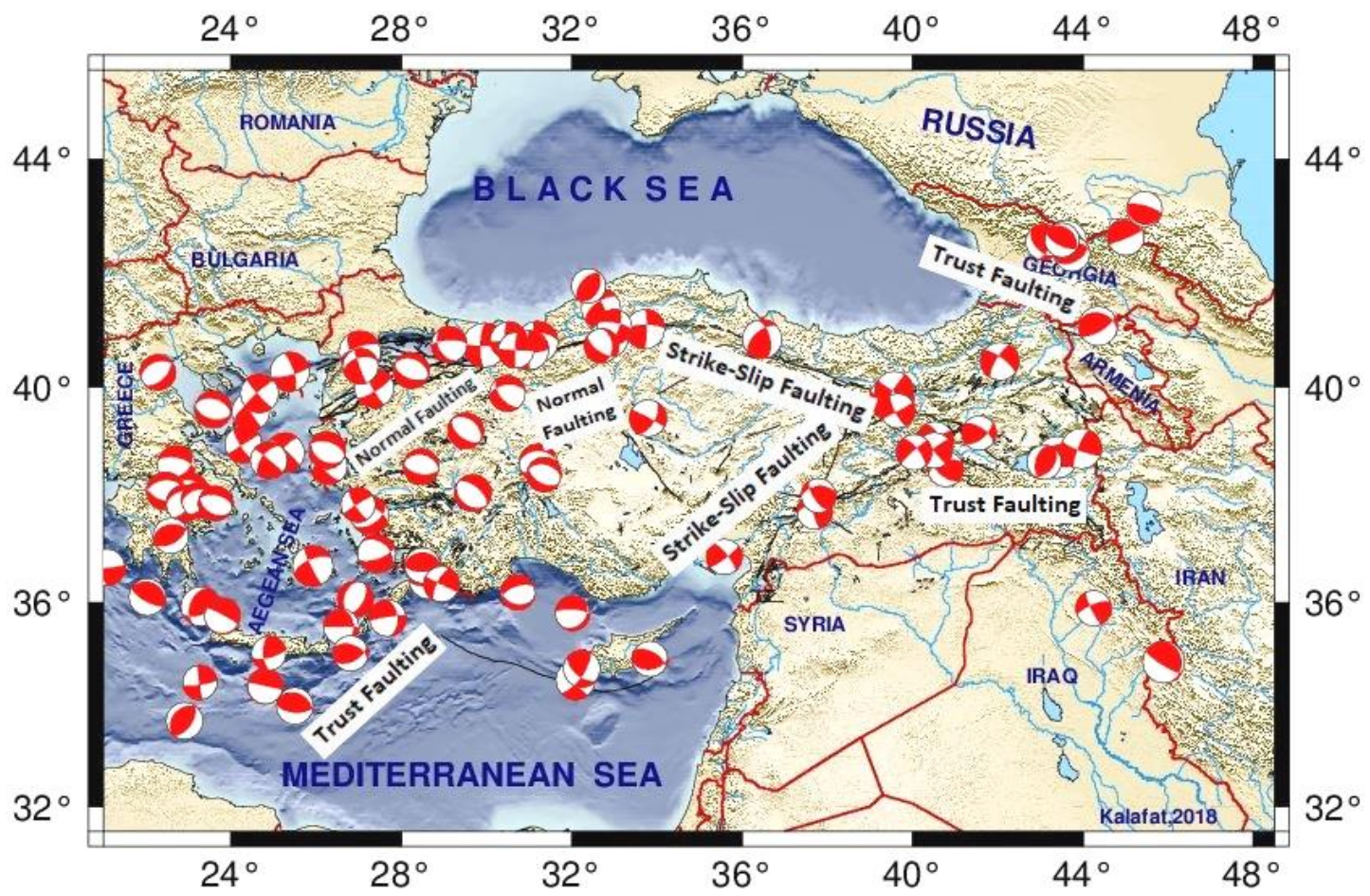

Fig. 4. Moment tensor solutions of earthquakes $\left(M_{w} \geq 6.0\right)$ that occurred during 1938-2017 in Turkey and surrounding area and main faulting types in the regions 


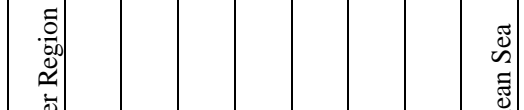

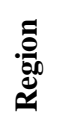

ڤั)

कृ

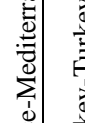

紊

赔

竞

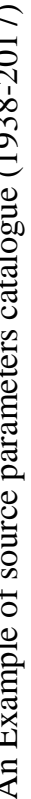

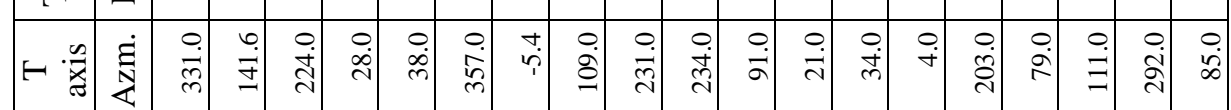

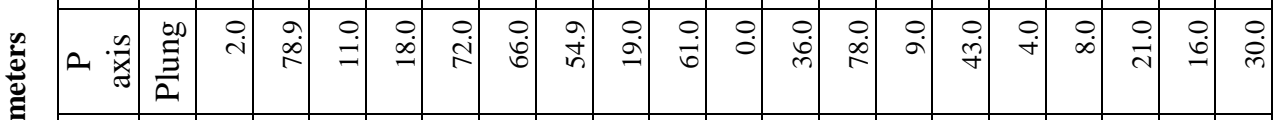

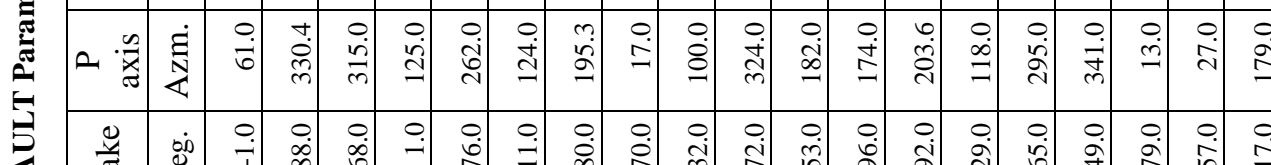

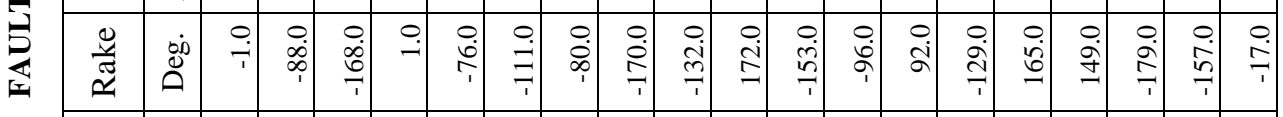
नि 䤑

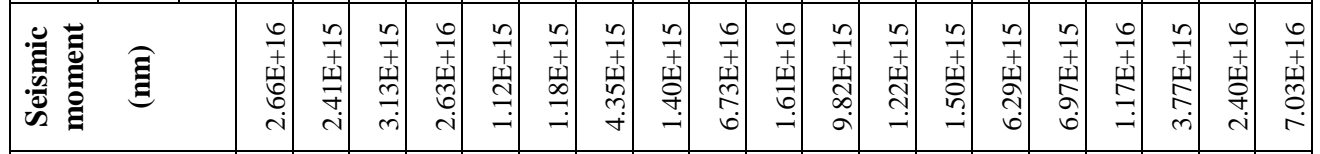

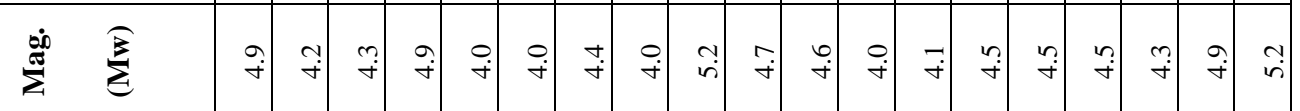

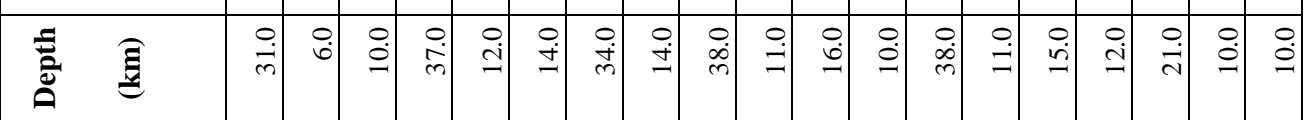

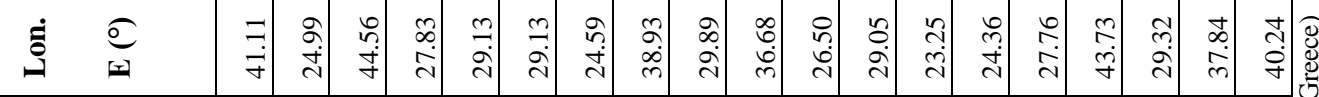

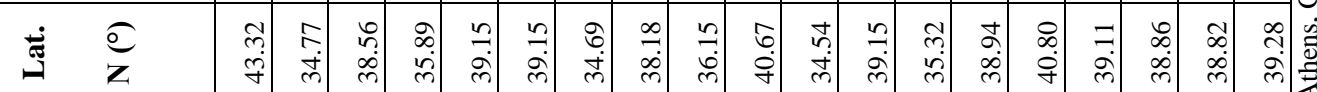

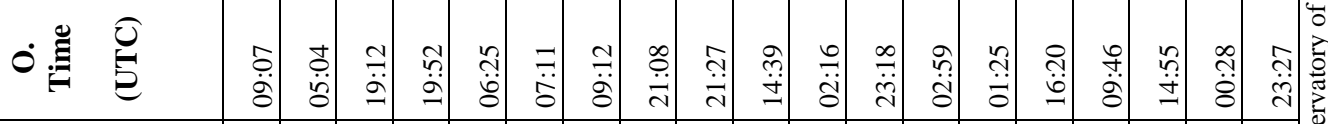

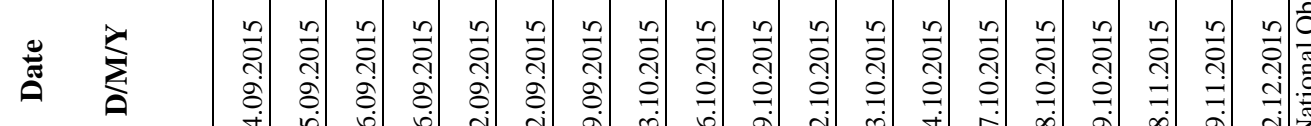
I

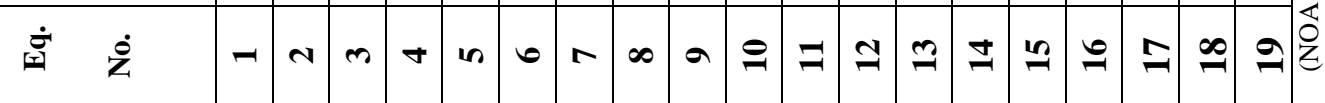




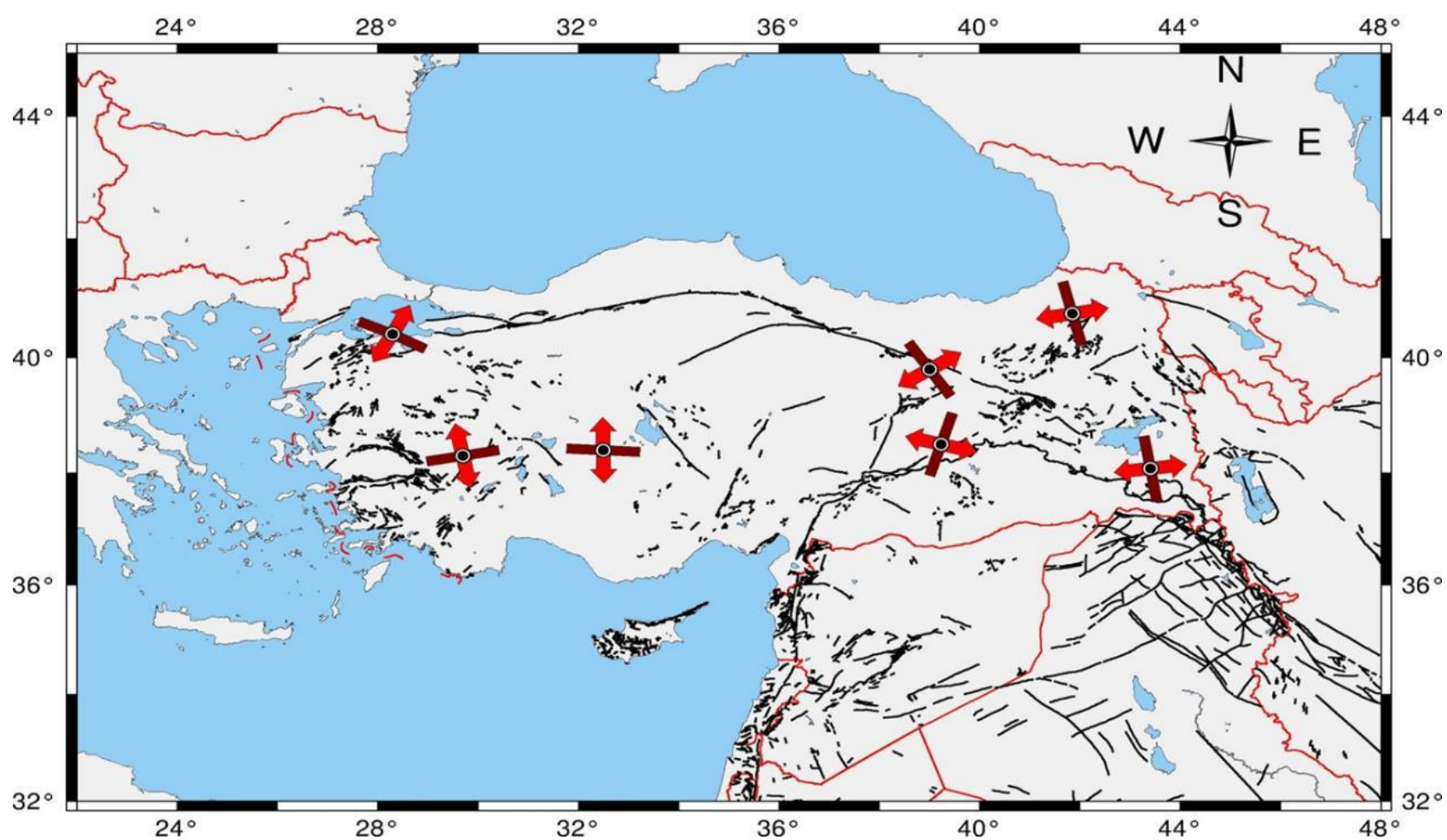

Fig. 5. The Regional stress tensor analysis: Regional main stress ( $\mathrm{P}$ and $\mathrm{T}$ ) directions (red arrows indicate maximum tensional, brown bars indicate main directions of maximum pressure)

$2^{\text {nd }}$ Region (North Anatolian Fault Zone NAFZ): Strike slip faults are widely effective and dominant P-axis directions are NW-SE extended in North Anatolia Fault Zone.

$3^{\text {rd }}$ Region (Western Turkey): In Western Turkey extension regime is heavily dominant and normal faults are equally dominant. Dominant P-axis directions are W-SW/-E-NE extended on a large scale.

$4^{\text {th }}$ Region (Eastern Anatolian Fault Zone EAFZ): In Eastern Anatolia Fault Zone strike slip faults are dominant and $\mathrm{P}$-axis directions are NE-SW extended generally.

$5^{\text {th }}$ Region (Central Anatolia): In Central Anatolia Region normal faults are widely dominant. In addition there are some oblique faults that have strikeslip component. In this region too $\mathrm{P}$-axis directions are generally E-W extended.

$6^{\text {th }}$ Region (Northeastern Turkey): Mechanism solutions in Northeast Anatolia Region reveal that strike slip faults are widely dominant. In this region P-axle

\section{REFERENCES}

Alptekin Ö. Focal mechanisms of earthquakes in Western Turkey and their tectonic implications. Ph.D. thesis, New Mexico Institute of Mining and Technology Socorro, New Mexico, 1973, $95 \mathrm{p}$.

Alptekin Ö., Nabalek J.N., Toksöz M.N. Source mechanism of Bartın earthquake on September 3, 1968 and thoughts on active tectonics of Black Sea. Bulletin of Earthquake Research, No. 60, 1985, pp. 5-38 (in Turkish). strikes are usually concentrated on N-NW-S-SE route.

$7^{\text {th }}$ Region (Southeast Turkey): In Southeast Turkey Region a compression-shortening regime is dominant. On a general scale trust faults are dominant however strike-slip faults and oblique faults with strike-slip components are also widely present. $\mathrm{P}$-axis directions are mostly concentrated NNW-SSE trending.

\section{Acknowledgments}

This study is supported by Boğaziçi University Research Projects Commission under SRP/BAP project No. 12280. We thank to Boğaziçi University Research Fund Commission and members. Also this study was partly supported by TUBITAK Scientific Human Resource Development Department's 2014 Year 2219-Post-Doctoral Research Fellowship Scholarship Program and the Massachusetts Institute of Technology (MIT) Earth Resources Laboratory (ERL).

\section{LITERATURE}

Alptekın Ö. Focal mechanisms of earthquakes in Western Turkey and their tectonic implications. Ph.D. thesis, New Mexico Institute of Mining and Technology Socorro, New Mexico, 1973, $95 \mathrm{p}$.

Barka A., Kadinski-Cade K. Strike-slip fault geometry in Turkey and its influence on earthquake activity. Tectonophysics, V. 7, 1988, pp. 663-684, DOİ: 10.1029/ TC007i003p00663.

Canıtez N., Büyükaşıkoğlu S. Seismicity of the Sinop Nuclear Power Plant Site, unpublished final report. İTÜ, İstanbul, 1984 
Alsan E., Tezuçan L., Başarır E., Ayhan E., Sancaklı N. July 5, 1983 Biga earthquake and aftershock activity. Earthquake Research Bulletin, V. 46, 1984, pp. 50-75 (in Turkish).

Barka A., Kadinski-Cade K. Strike-slip fault geometry in Turkey and its influence on earthquake activity. Tectonophysics, V. 7, 1988, pp. 663-684, DOİ: 10.1029/ TC007i003p00663.

Buyukaşıkoglu S. According to the seismological data, the characteristics of the Eurasian-African plate border in Anatolia and the eastern Mediterranean. Associate Professor Thesis, ITU MF, Istanbul, 1979 (in Turkish).

Canıtez N., Büyükaşıkoğlu S. Seismicity of the Sinop Nuclear Power Plant Site, unpublished final report. İTÜ, İstanbul, 1984.

Canıtez N., Toksöz M.N. Focal mechanism and source depth of earthquakes from body and surface wave data. Bull. Seismol. Soc. Am., V. 61, 1971, pp.1369-1379.

Canıtez N., Üçer S.B. Computer determinations for the fault plane solutions in and near Anatolia. Tectonophysics, V. 4 (3), 1967, pp. 235-244.

Comninakis P.E., Papazachos B.C. Seismicity of the Eastern Mediterranean and some tectonic features of the Mediterranean Ridge. Geological Society of America Bulletin, V. 83 , 1972, pp. 1093-1102.

Dewey J.F., Şengör A.M.C. Aegean and surrounding regions: Complex multiplate and continuum tectonics in a convergent zone. Geological Soc. of Am. Bull., V. 90, 1979, pp. 84-92.

Dreger D. Manual of the time-domain moment tensor inverse Code (TDMT_INVC) Release 1.1. Berkeley Seismological Laboratory, 2002, p. 18.

Eyidoğan H. A discussion on the mainshock and aftershock characteristics of the 13 March 1992 Erzincan earthquake. Geophysics, V. 6, No. 2, 1992, pp.103-112 (in Turkish).

Eyidoğan H. Seismotectonic properties of Bitlis-Zagros thrust Zone. Ph.D. Thesis, ITU Mining Faculty, Istanbul, 1983, 111p. (in Turkish).

Eyidoğan H., Jackson J. A seismological study of normal faulting in the Demirci, Alaşehir and Gediz earthquakes of 1969-1970 in the Western Turkey. Implications for the nature and geometry of deformation in the continental crust. Geophys. J. R. Astr. Soc., V. 81, 1985, pp. 569-607.

Eyidoğan H., Toksöz M.N., Gülen L., Nabalek J. Aftershock migration following the 1983 Horasan-Narman earthquake. MIT Earth Resources Laboratory unpublished report, 1987.

Gephard J.W. FMSI: A FORTRAN program for inverting fault/slickenside and earthquake focal mechanism data to obtain the original stress tensor. Comput. Geosci., V. 16, 1990, pp. 953-989.

Jackson J., McKenzie D.P. Active tectonics of the AlpineHimalayan Belt between western Turkey and Pakistan. Geophys. J. R. Astron. Soc., V. 77, 1984, pp.185-264.

Kalafat D. Catalogue of source parameters of moderate and strong earthquakes for Turkey and its Surrounding Area (1938-2015). Tubitak Technical Report, 2016, 90 p. (in Turkish).

Kalafat D. Investigation of the tectonic structures of Anatolia in terms of earthquake mechanisms. Earthquake Research Bulletin, No. 77, July 1998, pp. 1-217 (in Turkish).

Kalafat D. Seismicity and active tectonics of Southwestern Anatolia and Its Surroundings. Earthquake Research Bulletin, No. 63, 1988, pp. 5-98 (in Turkish).

Kalafat D. Investigation of some major earthquakes in recent years in terms of focus mechanism. Earthquake Research Bulletin, No. 66, 1989, pp. 6-33 (in Turkish).

Kalafat D. Source parameters of moderate and strong earthquakes for Turkey and its surrounding area (1938-2017). JpGU Meeting 2018 Japan Geoscience Union, Presentation No. S-SS08, 20-24 May 2018, Makuhari Messe Chiba, Japan, pp. 29-30.

Kalafat D., Gürbüz C., Üçer S.B. Investigation of the structure of the crust and upper mantle in the western Turkey. Earthquake Research Bulletin, No. 59, 1987, pp. 43-64 (in Turkish).
Canitez N., Toksöz M.N. Focal mechanism and source depth of earthquakes from body and surface wave data. Bull. Seismol. Soc. Am., V. 61, 1971, pp. 1369-1379.

Canitez N., Üçer S.B. Computer determinations for the fault plane solutions in and near Anatolia. Tectonophysics, V. 4 (3), 1967, pp. 235-244.

Comninakis P.E., Papazachos B.C. Seismicity of the Eastern Mediterranean and some tectonic features of the Mediterranean Ridge. Geological Society of America Bulletin, V. 83, 1972, pp. 1093-1102.

Dewey J.F., Şengör A.M.C. Aegean and surrounding regions: Complex multiplate and continuum tectonics in a convergent zone. Geological Soc. of Am. Bull., V. 90, 1979, pp. 84-92.

Dreger D. Manual of the time-domain moment tensor inverse Code (TDMT_INVC) Release 1.1. Berkeley Seismological Laboratory, 2002, p. 18.

Eyidoğan H., Jackson J. A seismological study of normal faulting in the Demirci, Alaşehir and Gediz earthquakes of 1969-1970 in the Western Turkey. Implications for the nature and geometry of deformation in the continental crust. Geophys. J. R. Astr. Soc., V. 81, 1985, pp. 569-607.

Eyidoğan H., Toksöz M.N., Gülen L., Nabalek J. Aftershock migration following the 1983 Horasan-Narman earthquake. MIT Earth Resources Laboratory unpublished report, 1987.

Gephard J.W. FMSI: A FORTRAN program for inverting fault/slickenside and earthquake focal mechanism data to obtain the original stress tensor. Comput. Geosci., V. 16, 1990, pp. 953-989.

Jackson J., McKenzie D.P. Active tectonics of the AlpineHimalayan Belt between western Turkey and Pakistan. Geophys. J. R. Astron. Soc., V. 77, 1984, pp. 185-264.

Kalafat D. Source parameters of moderate and strong earthquakes for Turkey and its surrounding area (1938-2017). JpGU Meeting 2018 Japan Geoscience Union, Presentation No. S-SS08, 20-24 May 2018, Makuhari Messe Chiba, Japan, pp. 29-30.

Kalafat D., Kekovalı K., Güneş Y., Yılmazer M., Kara M., Denız P., Berberoğlu M. A Cataloque of source parameters of moderate and strong earthquakes for Turkey and its Surrounding Area (1938-2008). Boğaziçi University Publication, No.1026, Bebek-İstanbul, 2009, 43 p.

Kalafat D., Toksöz N.M. Seismicity and tectonics of the Black Sea. SMP13-P04. Japan Geoscience Union Meeting, May $22^{\text {nd }}-26^{\text {th }} 2016$, Makuhari Messe, Tokyo-Japan, pp. 4-5.

McKenzie D.P. Active tectonics of the Mediterranean region. Geophys. J. R. Astr. Soc., V.30(2), 1972, pp. 109-185.

McKenzie D.P. Active tectonics of the Alpine-Himalayan Belt: Aegean Sea and surrounding regions. Geophys. J. R. Astr. Soc., V. 55, 1978, pp. 217-254.

Mercier J., Vergely P., Delibassis N. Comparison between deformation deduced from the analysis of recent faults and from focal mechanisms of earthquakes (An example: The Paphos region, Cyprus). Tectonophysics, V. 19, No. 4, 1973, pp. 315-332.

NOA National Observatory of Athens, Greece (http://www.noa.gr).

Nowroozi A.A. Focal mechanism of earthquakes in Persia, Turkey, west Pakistan and Afghanistan and plate tectonics of the Middle East. Bull. Seismol. Soc. Am., V. 62, 1972, pp. 823-850.

Öcal N. Determination of the mechanism of some Anatolian Earthquakes. A Symposium on earthquake mechanism: (J. Hodgson, ed.), Publ. Dom. Osb. Ottawa, V. 24, No. 10, 1960, pp. 365-370.

Pacheco J.F., Estabrook C.H., Simpson D.W., Nabelek J.L. Teleseismic body wave analysis of the 1988 Armenian earthquake. Geophy. Res. Letters, V. 16, No. 12, 1989, pp.1425-1428.

Pinar A., Honkura Y. Repture process of the 1992 Erzincan earthquake and its implication for seismotectonics in 
Kalafat D., Kekovalı K., Güneş Y., Yılmazer M., Kara M., Denız P., Berberoğlu M. A Cataloque of source parameters of moderate and strong earthquakes for Turkey and its Surrounding Area (1938-2008). Boğaziçi University Publication, No.1026, Bebek-İstanbul, 2009, 43 p.

Kalafat D., Toksöz N.M. Seismicity and tectonics of the Black Sea. SMP13-P04. Japan Geoscience Union Meeting, May 22nd - 26th 2016, Makuhari Messe, Tokyo-Japan, pp. 4-5.

Kalafat D., Yılmazer M., Kekovalı K., Kafadar N., Öğütçü Z., Horasan G., Güneş Y., Suvarıklı M. An example of the development of the seismic network on an institutional scale in Turkey: Development and modernization of the Kandilli Observatory and Earthquake Research Institute seismic network. Active Tectonic Research Group 9. Meeting ATAG9 Book of Abstracts, University of the Cumhuriyet MF, Sivas, 22 to 24 September 2005, pp.1-2 (in Turkish).

Kocaefe S., Ataman G. Seismo-tectonic events in Anatolia-1: Investigation of the region in the triangle of AntalyaFethiye-Denizli. Hacettepe University Journal of Earth Sciences, V. 2, No. 1, 1976, pp. 55-70 (in Turkish).

McKenzie D.P. Active tectonics of the Mediterranean region. Geophys. J. R. Astr. Soc., V. 30 (2), 1972, pp. 109-185.

McKenzie D.P. Active tectonics of the Alpine-Himalayan Belt: Aegean Sea and surrounding regions. Geophys. J. R. Astr. Soc., V. 55, 1978, pp. 217-254.

Mercier J., Vergely P., Delibassis N. Comparison between deformation deduced from the analysis of recent faults and from focal mechanisms of earthquakes (An example: The Paphos region, Cyprus). Tectonophysics, V. 19, No. 4 , 1973, pp. 315-332.

NOA National Observatory of Athens, Greece (http://www.noa.gr).

Nowroozi A.A. Focal mechanism of earthquakes in Persia, Turkey, west Pakistan and Afghanistan and plate tectonics of the Middle East. Bull. Seismol. Soc. Am., V. 62, 1972, pp. 823-850.

Öcal N. Determination of the mechanism of some Anatolian Earthquakes. A Symposium on earthquake mechanism: (J. Hodgson, ed.), Publ. Dom. Osb. Ottawa, V. 24, No. 10, 1960, pp. 365-370.

Öcal N., Üçer S.B., Taner D. October 6, 1964 ManyasKaracabey Earthquake. Ministry of National Education, Istanbul Kandilli Observatory Seismology Publications, No. 11, 1968 (in Turkish).

Pacheco J.F., Estabrook C.H., Simpson D.W., Nabelek J.L. Teleseismic body wave analysis of the 1988 Armenian earthquake. Geophy. Res. Letters, V. 16, No. 12, 1989, pp. 1425-1428.

Pinar A., Honkura Y. Repture process of the 1992 Erzincan earthquake and its implication for seismotectonics in eastern Turkey. Geophys. Res. Lett., V. 21, No. 18, 1994, pp. 1971-1974.

Pinar A., Kalafat D. Source process and seismotectonic implications of the 1995 and 1996 Cyprus, Eastern Mediterranean Region, earthquakes. Tectonophysics, V. 301, 1999, pp. 217-230.

Reilınger R., McClusky S., Vernant P., Lawrence S., Ergintav S., Cakmak R., Kadirov F., Guliev I., Stepanyan R., Nadariya M., Hahubia G., Mahmoud S., Sakr K., Arrajehi A., Paradissis D., Al-Aydrus A., Prilepin M., Guseva T., Evren E., Dmitrotsa A., Filikov S.V., Gomez F., Al-Ghazzi R., Karam G. GPS Constraints on continental deformation in the Africa-Arabia-Eurasia continental collision zone and implications for the dynamics of plate interactions. Journal of Geophysical Research, William Byrd Press for John Hopkins Press, United States, No. 111, 2006, pp. 1-26, DOI: $10.1029 / 2005 J B 004051$.

Saikia C. Modified frequency-wave number algorithm for regional seismo-grams using Filon's quadrature; modelling of Lg waves in eastern North America. Geophys. J. Int., V. 118,1994 , pp. 142-158.

Snoke J.A. FOCMEC: FOcal MEChanism determinations. International handbook of earthquake and engineering seis- eastern Turkey. Geophys. Res. Lett., V. 21, No. 18, 1994, pp. 1971-1974.

Pinar A., Kalafat D. Source process and seismotectonic implications of the 1995 and 1996 Cyprus, Eastern Mediterranean Region, earthquakes. Tectonophysics, V. 301, 1999, pp. 217-230.

Reilınger R., McClusky S., Vernant P., Lawrence S., Ergintav S., Cakmak R., Kadirov F., Guliev I., Stepanyan R., Nadariya M., Hahubia G., Mahmoud S., Sakr K., Arrajehi A., Paradissis D., Al-Aydrus A., Prilepin M., Guseva T., Evren E., Dmitrotsa A., Filikov S.V., Gomez F., Al-Ghazzi R., Karam G. GPS Constraints on continental deformation in the Africa-Arabia-Eurasia continental collision zone and implications for the dynamics of plate interactions. Journal of Geophysical Research, William Byrd Press for John Hopkins Press,United States, No. 111, 2006, pp. 1-26, DOI: 10.1029/2005JB004051

Saikia C. Modified frequency-wave number algorithm for regional seismo-grams using Filon's quadrature; modelling of Lg waves in eastern North America. Geophys. J. Int., V. 118, 1994, pp. 142-158.

Snoke J.A. FOCMEC: FOcal MEChanism determinations. International handbook of earthquake and engineering seismology (W.H.K.Lee, H.Kanamori, P.C.Jennings and C.Kisslinger, eds.), Academic Press. San Diego, Part B, 2003, pp.1629-1630.

Sokos E., Zahradnik J. Evaluating centroid moment tensor uncertainty in the new version of ISOLA software. Seismological Research Letters, V. 84, No. 4, 2013, pp. 656-665, DOI: 10.1785 .

Stewart S.G., Kanamori H. Complexity of repture in large strikeslip earthquakes in Turkey. Physics of the Earth and Planetary Interiors, V. 28, 1982, pp. 70-84.

Şengör A.M.C., Büyükaşıkoğlu S., Canıtez N. Neotectonics of the Pontides: 1mplications for "incompatible" structures along the North Anatolian Fault. J. Struct. Geol., V. 5, 1983, pp. 211-216.

Taymaz T. The source parameters of the Çubukdağ (W. Turkey) earthquake of 1986 October 11 . Geophys. J. Int., V. 113, 1993, pp. 260-267.

Taymaz T., Eyıdoğan H., Jackson J. Source parameters of large earthquakes in the East Anatolian Fault Zone (Turkey). Geophys. J. Int., V. 106, 1991b, pp. 537-550.

Taymaz T., Jackson J.A., McKenzie D. Active tectonics of the north and central Aegean Sea. Geophys. J. Int., V. 106, 1991a, pp. 433-490.

Alptekın Ö., Nabalek J.N., Toksöz M.N. 1985. 3 Eylül 1968. Bartın Depreminin Kaynak Mekanizması ve Karadeniz'in Aktif Tektoniği Hakkında Düşünceler, DAB, Sayı 60, s. 5-38.

Alsan E., Tezuçan L., Başarır E., Ayhan E., Sancaklı N. 5 Temmuz 1983 Biga depremi ve artçı deprem etkinliği. Deprem Araştırma Bülteni, V. 46, 1984, s. 50-75.

Buyukaşıkoglu S. Sismolojik verilere göre Anadolu ve doğu Akdeniz'de Avrasya-Afrika levha sınırının özellikleri. Doçentlik Tezi, İTÜ MF, İstanbul, 1979.

Eyıdoğan H. 13 Mart 1992 Erzincan depreminin ana şok ve art sarsıntı özellikleri üzerine bir tartışma. Jeofizik, V. 6, No. 2, 1992, s. 103-112.

Eyıdoğan H. Bitlis-Zagros bindirme ve kıvrımlı kușağının sismotektonik özellikleri. Doktora Tezi, İTÜ Maden Fakültesi, İstanbul, 1983, $111 \mathrm{p}$.

Kalafat D. Anadolu'nun tektonik yapılarının deprem mekanizmaları açısından irdelenmesi. Deprem Araştırma Bülteni, Say1 77, Temmuz 1998, s.1-217.

Kalafat D. Günaybatı Anadolu ve Yakın Çevresinin depremselliği, aktif tektoniği. DAB, Sayı 63, 1988, s. 5-98.

Kalafat D. Son yıllarda olmuş bazı büyük depremlerin odak mekanizması açısından irdelenmesi. DAB, Sayı 66, 1989, s. 6-33. 
mology (W.H.K.Lee, H.Kanamori, P.C.Jennings and C.Kisslinger, eds.), Academic Press. San Diego, Part B, 2003, pp.1629-1630.

Sokos E., Zahradnik J. Evaluating centroid moment tensor uncertainty in the new version of ISOLA software. Seismological Research Letters, V. 84, No. 4, 2013, pp. 656-665, DOI: 10.1785 .

Stewart S.G., Kanamori H. Complexity of repture in large strike-slip earthquakes in Turkey. Physics of the Earth and Planetary Interiors, V. 28, 1982, pp. 70-84.

Şengör A.M.C., Büyükaşıkoğlu S., Canıtez N. Neotectonics of the Pontides: implications for "incompatible" structures along the North Anatolian Fault. J. Struct. Geol., V. 5, 1983, pp. 211-216.

Taymaz T. The source parameters of the Çubukdağ (W. Turkey) earthquake of 1986 October 11. Geophys. J. Int., V. 113, 1993, pp. 260-267.

Taymaz T., Eyıdoğan H., Jackson J. Source parameters of large earthquakes in the East Anatolian Fault Zone (Turkey). Geophys. J. Int., V. 106, 1991b, pp. 537-550.

Taymaz T., Jackson J.A., McKenzie D. Active tectonics of the north and central Aegean Sea. Geophys. J. Int., V. 106, 1991a, pp. 433-490.
Kalafat D. Türkiye ve Çevresi Faylanma-Kaynak Parametreleri (MT) Kataloğu (1938-2015). A Catalogue of Source Parameters of Moderate and Strong Earthquakes for Turkey and its Surrounding Area (1938-2015). Tubitak Technical Report, 2016, 90 p.

Kalafat D., Gürbüz C., Üçer S.B. Batı Türkiye'de Kabuk ve Üst Manto yapısının araştırılması. Deprem Araştırma Bülteni, Say1 59, 1987, s. 43-64.

Kalafat D., Yılmazer M., Kekovalı K., Kafadar N., Öğütçü Z., Horasan G., Güneş Y., Suvarıklı M. Türkiye'de kurumsal ölçekte deprem ağının gelişimine bir örnek: Kandilli Rasathanesi ve DAE Deprem Ağının gelişimi ve modernizasyon. Aktif Araştırma Grubu 9. Toplantısı ATAG9 Bildiri Özetleri Kitab1, Cumhuriyet Üniversitesi MF, Sivas, 22-24 Eylül 2005, pp.1-2.

Kocaefe S., Ataman G. Anadolu'da sismo-tektonik olaylar-1: Antalya-Fethiye-Denizli üçgeni içinde yer alan bölgenin incelenmesi. HÜ yer Bilimleri Yayın organ1, C.2, No. 1, 1976, s. 55-70.

Öcal N., Üçer S.B., Taner D. 6 Ekim 1964 Manyas-Karacabey Depremi. MEB, İstanbul Kandilli Rasathanesi Sismoloji Yayınları, No. 11, 1968.

\title{
ИСХОДНЫЕ ПАРАМЕТРЫ СРЕДНИХ И СИЛЬНЫХ ЗЕМЛЕТРЯСЕНИЙ В ТУРЦИИ И ПРИЛЕГАЮЩИХ К НЕЙ РАЙОНАХ (1938-2017 ГГ.)
}

\author{
Калафат Д. \\ Университет Богазичи, Обсерватория и Институт исследования землетрясений Кандилли \\ 34684, Ченгелькой-Станбул, Туриия: e-mail: kalafato@boun.edu.tr
}

\begin{abstract}
Резюме. Главной целью исследования являются вычисление параметров очагов землетрясений с помощью метода инверсии, подготовка банка типов тектонических нарушений на территории Турции и прилегающих районов согласно фокальному механизму и тензору сейсмического момента, а также расчет региональных напряжений. Основной задачей является сбор исходных параметров - механизмов тектонических нарушений, произошедших в Турции и прилегающих районах, в полную базу данных. Эта работа проводилась с намерением пополнить и обновить ранее проведенные исследования. Надо отметить, что в Турции инструментальная сейсмология применяется с 1938 года. Приблизительно 70\% параметров тектонических нарушений были вычислены в рамках данного исследования. Статья также посвящена подготовке базы однородных и комплексных данных путем расчета всех недостающих параметров ранее произошедших землетрясений. Подготовлена карта региональных типов тектонических нарушений с помощью набора тензора сейсмического момента, расчета региональных напряжений и осевых ориентаций в регионах Турции, относящихся к различным тектоническим режимам, используя параметры каждого землетрясения (направление, простирание, угол наклона, сейсмический момент Мо, моментная магнитуда $\mathrm{M}_{\mathrm{w}}$, оси $\mathrm{P}$ и Т азимута сжатия и растяжения). В итоге в статье обобщены параметры очагов 1950 землетрясений $\left(\mathrm{M}_{\mathrm{w}} \geq 4.0\right)$ и решений плоскости тектонического нарушения, причем большая их часть рассчитана в этом исследовании.
\end{abstract}

Ключевые слова: фокальный механизм, Туриия, тензор сейсмического момента, параметры очагов, моментная магнитуда

\section{TÜRKIYYDə Və BITTISSIK RAYONLARDA ORTA Və GÜCLÜ ZəLZəLӘLəRIN BAŞLANĞIC PARAMETRLəRI (1938-2017-CI İLLOR)}

\author{
Kalafat D. \\ Boğaziçi Universiteti, Kandilli Zalzalalarin Tadqiqi Institutu va Rasadxanası \\ 34684, Çəngalkoy-İstanbul, Türkiya: e-mail: kalafato@boun.edu.tr
}

\begin{abstract}
Xülasə. Tədqiqatın başlıca məqsədi inversiya metodunun köməyi ilə zəlzələ ocaqlarının parametrlərinin hesablanması, seysmik momentin fokus mexanizminə və tenzoruna müvafiq olaraq Türkiyə ərazisində və bitişik rayonlarda tektonik pozulmaların tiplərinin bankının hazırlanmasından, həmçinin regional gərginliklərin hesablanmasından ibarətdir. İşin əsəs vəzifəsi başlangıc parametlərinin - Türkiyədə və bitişik rayonlarda baş vermiş tektonik pozulmaların mexanizmələrinin - məlumatların bütov bazasına toplanmasından ibarətdir və bu da tədqiqatçıların diqqətinə çatdırmaq məqsədi daşıyır ki, instrumental seysmologiya 1938-ci ildən tətbiq edilməyə başlanmışdır və bu gün də istifadə olunur. Bu iş əvvəllər aparılmış tədqiqatların təzələnməsi və təkmilləşdirilməsi məqsədilə aparılmıșdır. Tektonik pozulmaların parametrlərinin təxminən 70\%-i bu tədqiqatın çərşivəsində hesablanmıșdır. Məqalə həmçinin əvvəllər baş vermiş zəlzələlərin bütün çatışmayan parametrlərinin hesablanması yolu ilə həmcinsli və kompleks məlumatların bazasının hazırlanmasına həsr edilmişdir. Hər bir zəlzələnin parametrlərindən (istiqamət, uzanma,əyilmə meyli, seysmik moment Mo, zaman maqnitudası $\mathrm{M}_{\mathrm{w}}$, sıxılma və gərginlik azimutunun $\mathrm{P}$ və $\mathrm{T}$ oxları) istifadə etməklə Türkiyənin regionlarında regional gərginliklərin və ox istiqamətlərinin hesablanmasının, seysmik momentin tenzor dəstinin köməyi ilə tektonik pozulmaların regional tiplərinin xəritəsi hazırlanmışdır. Nəticədə məqalədə 1950 zəlzələ ocaqlarının $\left(\mathrm{M}_{\mathrm{w}} \geq 4.0\right)$ parametrləri və tektonik pozulma müstəvisinin həlli ümumiləş̧irilmiş̧ir.
\end{abstract}

Açar sözlor: fokus mexanizmi, Türkiyə, seysmik momentin tenzoru, ocaqların parametrləri, moment maqnitudası 